\title{
Popular Music, Gender and Sexualities
}

\author{
Sheila Whiteley \\ Professor Emeritus, University of Salford \\ s.whiteley@salford.ac.uk
}

\begin{abstract}
This paper responds to Philip Tagg's 2011 discussion of the state of popular music studies since the formation of the International Association for the Study of Popular Music by foregrounding issues concerning the current position of popular music studies, gender and sexualities. It provides both a personal insight into teaching practice and publications, and explores the current position of women in the music industry.
\end{abstract}

Keywords: IASPM, popular music, pop, rock, mainstream, gender, sexualities, queer, popular music studies

Rereading Philip Tagg's article, 'Caught on the Backfoot: Epistemic Inertia and Visible Music' (Tagg, 2011), which discusses his thoughts on the current position of popular music studies, I have to admit that I applaud his forthrightness and share many of his regrets. The founding of IASPM and the Cambridge University Press Journal Popular Music has been important for so many of us, but sadly, it is also true that we have not yet achieved the initial goals set by Tagg and other IASPM founder members. Not least, there is still continuing prejudice from many mainstream/conventional musicologists, despite the occasional nod to artists such as Björk and the Beatles. I am also aware that courses exploring the political and cultural implications of gender are somewhat of a rarity in popular music studies. Even so, my glass is, I reckon, half full rather than half empty as I see our academic children - and indeed grandchildren continuing to fly the flag of equality for popular musicology. Publishers, such as Ashgate, have championed the cause of popular music studies, and Routledge, Oxford University Press, Edinburgh University Press and Cambridge University Press, among others, are supportive of our work in the field. As such, my main gripe and disappointment concerns copyright - a concern also shared with Tagg. How can we encourage our popular music students to support their arguments by reference to carefully transcribed extracts (far more difficult than simply going to a score) when we continue to be short-changed by the rules concerning fair use, which means there are increasingly fewer and fewer examples for them to follow. We have tried and will continue to try to overcome this major hurdle, but it is evident that publishing houses are reluctant to put their heads on the block, despite efforts by Philip Tagg, Nicolas Cook, Simon Frith, Derek Scott and me.

My own involvement in popular music studies has been largely in the field of popular music and gender and, as such, the thrust of my article is to argue for its continuing importance within the field of popular musicology/ethnomusicology. As such, I offer a brief question and answer session to set the ball rolling.

Q. Why did you introduce a module on gender and sexualities into Salford University's honours degree, Popular Music and Recording? 
A. Having delivered my first-year course on Style and Genre for two years, it occurred that across its twenty two-hour lectures, very few women musicians were represented, and those who were came (possibly predictably) from folk, pop, and the singer-songwriter traditions. No student had asked why women were under-represented and, as such, I considered it both important and relevant to explore the relationship between genre and gender in a dedicated course.

My second year module on Gender and Sexualities was launched by a one-day conference at the University of Salford (1994), which, in turn, developed into Sexing the Groove: Popular Music and Gender (Routledge, 1997). As I wrote in the Introduction

The collection of articles presented in this book provides a diverse range of perspectives, discussions and debates with one common mission in mind: to explore the ever-changing modes of expression within popular music and, in particular, its relationship to genders and sexualities. (xiii)

With contributions from leading pop musicologists and cultural theorists ${ }^{1}$, its groundbreaking chapters are evocative of a period when popular music took on and challenged the establishment by spotlighting the very real relationship between popular music, sexuality and gender. As those of us involved in this problematic area were all too aware, there was a very real need to explore and discuss the politics of identity, and we saw ourselves as rebellious in contesting the established citadels of traditional musicology, exploring meaning by drawing on sister disciplines (film theory, media studies, sociology and popular culture) but always with popular music firmly at the centre of discussion. Above all, our focus on performers, and the rituals of style and gendered identity was sexy - a possible reason why many in the establishment refused, and continue to refuse to admit that the relationship between sex/sexuality/gender and popular music is a major issue both in academic courses and in real life - a concern l'll return to later in my discussion. Sexing the Groove formed the backbone of my initial second year course, but the very real shortfall in books on popular music and gender lead to further publications - Women and Popular Music (2000) and Too Much Too Young (2005) - and I am always both delighted and humbled by e-mails from students who have found these to be an inspiration for their own research.

It is important to acknowledge the very real role that conferences play in the dissemination of ideas. IASPM, in particular, has made an invaluable contribution to my academic life, and the opportunity of serving on the IASPM International Committee and thus being involved in the planning of two conferences, the first at Turku (2001), the second at Montreal (2003), was an added bonus. Not least it offered a rare opportunity to "wrench queering from the doldrums of generalized gender debates and to foreground current issues - not least of which are those concerning ethnicity and class" (Whiteley and Rycenga, 2006: xi). I was thus delighted that original contributors to Queering the Pitch: The New Lesbian and Gay Musicology (1994) agreed to take part in a panel discussion at the Montreal conference, which evaluated the significance of the original text and updated many of the earlier discussions. ${ }^{2}$ Panellists included Jennifer Rycenga, Professor of Comparative Religious Studies and Co-ordinator of Women's Studies at San José State University in California, and together we edited Queering the Popular Pitch (2006). It included a chapter by Vanessa Knights, who many of us remember and who is still sadly missed. More recently, I am co-editing, with Fred Maus, The Oxford Handbook of Music and Queermess (forthcoming) and I am delighted that this will include chapters from such significant academics as Jack (Judith) Halberstam and Jodie Taylor, whose book Playing It Queer. Popular Music, Identity and Queer World-Making (2012) evidences the continuing importance of queer to issues concerning identity and subjectivity in popular music courses. As Jennifer and I wrote earlier, "By using the term queer - as opposed to lesbian and gay - the authors show how same-sex desire can be foregrounded without designating which sex is 
desiring/being desired and, as such, a certain fluidity is achieved that refuses genderbased constructions. In short, queer becomes the taboo-breaker" (Whiteley and Rycenga, 2006: xiv).

While conferences have played an important role for both established and emerging scholars of popular music and gender, team teaching with Freya Jarman also opened up new directions in exploring masculinities and popular music and lead to her edited text Oh Boy! Masculinity and Popular Music (2007). The Introduction (written with lan Biddle) provides students with important discussion points, not least the "construction and representation of masculinity in popular music" (3) and the ways in which "cultural forces work ... to naturalize gender formations" (13) Most recently, I have been asked to write a chapter on the teaching of gender and sexuality for the Sage Handbook of Popular Music (eds. Andy Bennett and Steve Waksman). Simone Kruger (Liverpool John Moores), Helen Davies (Liverpool Institute of Performing Arts), Lucy Green (University of London), Lisa Colton (University of Huddersfield), and Freya Jarman (University of Liverpool), among others, have given me outlines of their approach and relevant teaching modules as I don't feel it would be appropriate just to "tell it my way".

I have also been fortunate in both tutoring masters and doctoral students and in receiving invites to be external examiner in Australia, Norway and the UK for students specialising in popular music and gender studies, and it is exciting to see their publications coming out in major international publishing houses. Derek Scott and I also spent many happy Thursday afternoons with our postgraduate students, a time I remember with particular fondness. It is especially good to see Nicola Smith's chapter 'Beyond the Master Narrative of Youth: Researching Ageing Popular Music Scenes' in The Ashgate Research Companion to Popular Musicology (2009: 427-445) and Nicola Spelman's Popular Music and the Myths of Madness (2012) receiving such great reviews. A big reminder of how important Salford's groundbreaking honours degree, Popular Music and Recording, has been for students past and present.

I am also aware that a passion for identity politics extends well beyond the lecture theatre - not least if we have been affected ourselves. It is sad to see, for example, that there are still so few Chairs of Music/Popular Music held by female academics. As the BBC News Channel reported, "Although there had been a small increase $(0.7 \%)$ in the proportion of females at professor and also at senior lecturer/researcher level $(0.8 \%)$ since $2004-05$, at other grades the gender split remained almost static... HESA figures also showed that $10.7 \%$ of academic staff who chose to state their ethnic background were from an ethnic minority... [Yet] for the past decade, more women than men have been attending university as students" (BBC, 2007). It is also evident that gender imbalance is not confined to academic institutions. My very real concern for gender equality and the ways in which musicians have been treated by the music industry also lead to two European Social Research awards ${ }^{3}$, which explored both exploitation and the very real lack of women in studio technology. This problem is still to be rectified and the continuing importance of courses on popular music, gender and sexualities is evidenced in the UK Music Industries Equality and Diversity Charter (UK Music Industry, 2012), which aims to redress the very real gender imbalance in commercial music.

As its website states, it takes a broad and inclusive interpretation of equality and diversity, and will help champion everything the music industry does to improve its recruitment practices, diversify its decision making and up its outreach. It also asks organisations, businesses and individuals to commit to two or more actions in 2012 aimed at improving equality and diversity in the industry. These include:

- Recruiting from a wide talent pool

- Improving equality and diversity at senior decision making levels 
- Participating in, or running activities that promote equality and diversity in the music industry

- Sharing methods of increasing equality and diversity

Jo Dibble, the chief executive of UK Music adds, "Diversity is a massive asset for the UK music industry. Our creative talent and the audience who enjoy our music is, without doubt, diversity personified." (ibid) Yet for me, the current success of female singers veils the fact that inequality is still rife and that women remain underrepresented in popular music, whether we are talking about performers, A\&R (artist and repertoire), studio managers, or simply in terms of equal opportunity within its various genres. Jodie Taylor recently sent the following:

I went to Soundwave last weekend which is a huge metal/darkwave festival in Australia.

Among many others I saw Sisters of Mercy (for the first time ever!) and some classics like

Bad Religion and of course one of my idols Marilyn Manson. Sadly, in a 12 hour festival

with 7 stages playing at once there were only 2 bands that had women in them. Very discouraging for aspiring women of hard rock/industrial. ${ }^{4}$

May 2012 saw my second visit to the SPOT Festival ${ }^{5}$ (Aarhus), this time to discuss the implications of Denmark's recently published research paper, 'Gender Balance in Popular Music' (https://www.artisten.dk). The findings show that males continue to dominate not only universities and academies concerned with music, but also the decision-makers in the unions and other powerful institutions, the Danish Arts Foundation (with males receiving the majority of grants and financial aid), record companies, the media, venues and festivals. Needless to say, this has major implications for women, not simply as musicians, but also those who aspire to positions of influence in the Industry itself.

I have also given keynotes at the Sorbonne ('The vision of possibility: popular music and femininity' April, 2011) for their lecture series on 'Gender at Work', and Chichester University, as part of their annual conference to celebrate Women's Day (March 8, 2012). In 2013, I am speaking at an interdisciplinary conference on 'Voice [Body] Image' at the Centre of Gender Studies, Graz University (Austria), and an exhibition and symposium on 'Shepop - Women Make Music' at Gronau (Germany). Both will be exploring and celebrating the role of women in popular music, while acknowledging the continuing problems surrounding gender and genre. My guiding thoughts relate to two connected statements: "hegemonic gender formations are especially effective in enforcing the criteria to which the subject must conform if $s /$ he desires the attendant privileges of a hegemonic gender identity" (Biddle and Jarman-Ivens, 2007: 5), and "for a woman to identify as a woman is a culturally enforced effect" (Kotz, 1992: 84). These, in turn, relate to issues surrounding cultural conformism and the ways in which popular music refers to "lived experience and the broader patterns of discourse and culture that [it] both mirrors and actively produces" (Brett et al, 1992: vii-ix). They are concerns that have been central to my investigations into the cultural and political implications that lie behind popular music and gender, that is to say that the power of popular music "not only represent(s) to us how things are, but also help(s) to construct the very categories of identity through which we experience them" (Middleton, 2000: 231). As I recently wrote in my chapter, 'Following in Mother's Silent Footsteps: Revisiting the Construction of Femininities in 1960s Popular Music':

My thirteen year old grand-daughter is in love with Justin Bieber. So is her best friend. He is an important element in their friendship: they can sing all his songs; they know his likes and dislikes; what he looks for in a potential girlfriend. They contribute regularly to updates on his fan club, chatting about his latest concerts, rhapsodizing about his looks. They are also academically bright, articulate about their views on life. (Bennett et. al., forthcoming).

I think back to my own imaginary 'love affairs' with sixties rock stars Mick Jagger and Jim Morrisson and realize I remember most of their repertoire. But then, I also 
know that I would be able to sing along to most of the hits from the 1960s and that I have not only internalized lyrics by The Beatles and other iconic figures, but also the 'dolly-bird pop' of Lulu and Cilla, albeit seemingly balanced by Sandie Shaw and Dusty Springfield. I like to think I was a rebel, influenced by French Existentialism. I still have my 1967 copy of Mikhail Bulgakov's The Master and Margarita (1967), a book given to Mick Jagger by Marianne Faithfull, which fed the satanic fantasy associated with the Rolling Stone's hit 'Sympathy for the Devil' (1968). My trek to San Francisco in 1968 surely evidenced countercultural ideals, albeit fed by my love of The Doors. I was a feminist, immersed in women's lib (as it was called at the time), and yet, as Sandi Toksvig writes:

It is when you go to the supermarket that you see the true triumph of women's liberation... These are the women who have achieved the serenity of motherhood, the satisfaction of a creative career and the ability to achieve orgasm during the spin cycle of their many efficient household appliances. Women who know how to fondle a melon into ripeness, a child into slumber and a man into ecstasy. Is it true? Wander down any aisle and find out...

Slightly overweight, slightly unfit, slightly distracted. Minimal makeup, maximum permapress. These are the women who aren't supposed to exist any more. They were supposed to have woken to the clarion call of liberation given in the 1960s and 1970s and reached out to fulfill themselves. Instead these women had stolidly followed in their mother's silent footsteps. (2002: 24).

As discussed in my chapter, Toksvig's observation relates to my investigation into the sixties, more specifically what it is that influenced seemingly articulate women, motivated by the writings of Germaine Greer and other feminists of the time, to capitulate and follow "in their mother's silent footsteps" (lbid).

Further, while pop is acknowledged as the mainstream discourse of popular music and, as such, most likely to (re)produce conventional femininities, it is surprising to discover that rock - the so-called "voice of the 1960s counterculture" was equally conservative in its framing of gender. While its male stars blatant sexuality inspired both moral outrage and a boost to their performance credentials, women remained subject to sexual stereotyping or an often overt sexism, as discussed in Women and Popular Music (2000). Not least they were largely excluded from the guitar-lead rock fraternity, its phallocentricism, and highly sexualized performance codes. Questions thus arise as to why, with all the hype of the 1960s sexual revolution (which implied that the stranglehold of traditional gendered roles might be weakening) did rock undermine the ideology that defined women's liberation? Why was the struggle for liberation seen mainly "as the province of men" (Roszak, 1970: 65). Why were women so often relegated to the role of "camp followers" (ibid), and was this so dissimilar from the dubious accolade of "pussy power" perpetuated by the Underground magazine, Oz? Why were women in 1960s Britpop described as 'dolly birds' or 'pop tarts' by otherwise pioneering feminists, and why was there no real challenge to the established status quo? More specifically, as addressed in a collection edited by Bennett, Baker and Taylor (2013), why and how did mainstream pop and rock continue to perpetuate the normative gender discourse that dominated the 1960s and beyond?

Surely these are the sort of question we can ask of every era, every genre, whether we are discussing The Beatles, Morrissey, Adele or the latest pop stars. It also evidences why gender matters, and why popular music studies should continue to flag up the undoubted importance of its underlying presence in undergraduate and postgraduate courses alike. As I wrote in my chapter, 'Popular Music, Women and Human Rights', it is an inexcusable fact that "significant numbers of the world's population are routinely subject to torture, starvation, terrorism, humiliation and even murder simply because they are female... that women are discriminated against and abused on the basis of gender" (2011: 157). Despite the Universal Declaration of Human Right's (UDHR) stating that "Everyone has the right to freedom of opinion and 
expression", the freedom for women and sexual minorities to represent themselves through the arts as a form of cultural self-expression remains contentious ${ }^{7}$. My discussion of 'The Magdalena Laundries' (Turbulent Indigo, 1994) is but one reason why we rely on storytellers such as Joni Mitchell to create a voice for the dead or forgotten. We need artists and musicians who can inhabit the pain and expand our understanding of both the victim(s) and the situation through "direct confronting speech, commingled with imagery and a caustic voice" (Whitesell, 2008: 77). The suppression of voices, whether in so-termed world music, in heavy metal, rock or in countries where freedom of speech is suppressed is, for me, critical and as such, "the right to freedom of opinion and expression, and the freedom to hold opinions without interference and to seek, receive and impart information and ideas through any media and regardless of frontiers" (UDHR, Article 19), not least music as the voice of the people, remains crucial to the role of popular music studies. As lyrics tellingly inform us, "it's a lonely road" (Mitchell, 1971) but if we are to ignore gender inequality in popular music, we are not only failing popular music studies, we are failing ourselves.

It is for this reason that IASPM is so important in reaching out both to academics, students and practitioners of popular music. Across its history it has facilitated contact with countries where popular music studies is, at best, a tag-on (no pun intended!) and, as such, it was exciting that so many responded to our recent call for papers on Music and Virtuality (Whiteley and Rambarran, OUP, forthcoming), 34 ground-breaking articles, from the UK, Canada, America, Australia, Mexico, Finland, Germany, Norway, and Denmark evidenced the power of the IASPM website in alerting international scholars of popular music to publishing opportunities. It also fulfilled many of the objectives outlined by Tagg: it is interdisciplinary, interprofessional (including articles by composers, musicians, and a virtual collaboration on a circus train), producers, fans, musicologists, sociologists... I could go on, but watch this space for updates. It was a similar story for Counterculture(s) and Popular Music - which includes an article on the border-crossing soundscape in 1960s Berlin, apocalyptic Christianity and, in the French edition, Muslim Tacquacore (Whiteley and Sklower, forthcoming). The three collections will be published in France (Éditions Mélanie Seteun, September and December 2012) and in a collaborative volume with Ashgate (2014). For those of us who have retired from full-time academe, IASPM still offers a very real space for communication and ongoing collaboration, reaching out to others with a passion for popular music studies and meeting up with old and new friends at Bi-ennial and International conferences. For me, this is a very real success and a tribute to its founder members.

\section{Endnotes}

${ }^{1}$ I would like to acknowledge Dave Sanjek's work here, and at Salford University when he took over the role of Research Professor in Popular Music. His untimely death came as a very real shock to all his colleagues and his wealth of knowledge, good humour and friendship is greatly missed

2 The full transcripts were included in the GLSG Newsletter for the Gay and Lesbian Study Group of the American Musicological Society 14, no.1, Spring 2004.

${ }^{3}$ The second a collaborative bid with Prof. Derek Scott

4 Personal communication with Jodie Taylor, Research Fellow at the Queensland Conservatorium Research Centre.

5 The SPOT Festival takes place annually in Aarhus, Denmark and features established and new bands in rock, pop and related genres. It aims to establish international networks through the exchange of concerts and cultural / commercial experiences. These include lectures and seminars. See http://www.the-nmo.com/8/post/2012/04/spot-festival-aarhus-denmark.html.

${ }^{6}$ The European multidisciplinary journal, Travail, Genre et Sociétés (Revue semestrielle publiée avec le concours du Centre National de la Recherche Scientifique et du Centre National du livre. Publ. Paris. Arman Colin/Mage) has published research into gender differences in 
society and the workplace since 2008, not least its prescriptive emphasis on largely masculinist constructions of gender roles.

${ }^{7}$ It is interesting to note that Billie Holiday's recording company, Columbia, refused to record the anti-lynching song 'Strange Fruit'. Its powerful lyrics ('the bulging eyes and twisted mouth", the "black bodies swaying in the Southern breeze') were considered too controversial. A deal was made with Columbia, who loaned her to Commodore, and 'Strange Fruit' was cut on April 20, 1939 at Brunswick's World Broadcasting Studios with Frankie Newton's Café Society band. (see Nicholson, 1996, p.113)

\section{Coda}

I am delighted to see that Philip Tagg is Visiting Professor at Salford University. With his passion for popular music studies, we are all relying on him to keep the flag flying.

\section{References}

\section{Bibliography}

BBC News Channel (2007) Male Professors outnumber Women. 14 May. http://news.bbc.co.uk/1/hi/education/6653705.stm Accessed: 15 Jul 2012.

Bennett, Andy, Baker, Sarah and Taylor, Jodie Eds (2013) Redefining Mainstream Popular Music. London and New York: Routledge.

Brett, Philip, Wood, Elizabeth, Thomas, Gary C. Eds (1994) Queering the Pitch. The New Gay and Lesbian Musicology. London and New York: Routledge.

Bulgakov, Mikhail (1967) The Master and Margarita. London : The Harvivill Press, first issued in Fontana Books 1969.

Forsell, Anne Ed (2008-2012) Travail, Genre et Sociétés. Revue semestrielle publiée avec le concours du Centre National de la Recherche Scientifique et du Centre National du livre. Paris. Arman Colin/Mage.

Jarman-Ivens, Freya Ed (2007) Oh Boy! Masculinities and Popular Music. London and New York: Routledge.

Kotz, Liz (1992) "The Body You Want: Liz Kotz Interviews Judith Butler", Artforum Vol. 31 (3): 82-89

Middleton, Richard Ed (2000). Reading Pop. Approaches to Textual Analysis in Popular Music. Oxford and New York: Oxford University Press

Nicholson, Stuart (1996) Billie Holiday. London: Indigo

The New Music Office, SPOT Festival (2012) http://www.thenmo.com/8/post/2012/04/spot-festival-aarhus-denmark.html Accessed 5 May 2012.

Roszak, Theodor (1970) The Making of a Counter Culture. New York: Faber and Faber.

Smith, Nicola (2009) "Beyond the Master Narrative of Youth: Researching Ageing Popular Music Scenes" in Scott, Derek B. Ed The Ashgate Research Companion to Popular Musicology. Farnham/Burlington: Ashgate: 427-445.

Spelman, Nicola (2012) Popular Music and the Myths of Madness. Farnham and Burlington: Ashgate.

Tagg, Philip (2011) "Caught on the Backfoot: Epistemic Inertia and Visible Music", IASPM Journal, 2 (1-2):

Toksvig, Sandi (2002) Flying Under Bridges. London: Time Warner. Originally printed Warner Books, 2001.

UK Music Industry (2012) Equality and Diversity Charter http://www.ukmusic.org/edc Accessed 14 Feb 2012.

Whiteley, Sheila- 
(1997) Sexing the Groove. Popular Music and Gender. London and New York: Routledge.

(2000) Women and Popular Music. Sexuality, Identity and Subjectivity. London and New York: Routledge.

(2005) Too Much Too Young. Popular Music, Age and Identity. London and New York: Routledge

(2009) Research Strategies of the Unruly Feminine Scenes. Scott, Derek B. Ed The Ashgate Research Companion to Popular Musicology. Farnham and Burlington: Ashgate: 205-220.

(2011) The Vision of Possibility: Popular Music, Women and Human Rights. Ian Peddie Ed Popular Music and Human Rights: Volume 1: British and American Music. Farnham: Ashgate: 157-170

(2013) Following In Mother's Silent Footsteps: Revisiting the Construction of Femininities in 1960s Popular Music. Bennett, Andy, Baker, Sarah and Taylor, Jodie Eds Redefining Mainstream Popular Music. London and New York: Routledge.

Whiteley, Sheila and Maus, Fred, Eds (forthcoming) The Oxford Handbook of Music and Queerness. Oxford and New York: Oxford University Press.

Whiteley, Sheila and Rycenga, Jennifer (2006) Queering the Popular Pitch. London and New York: Routledge.

Whiteley, Sheila and Rambarran, Shara Eds (forthcoming) The Oxford Handbook of Music and Virtuality

Whiteley, Sheila and Sklower, Jedediah Eds (2012) Counterculture(s) and Popular Music. Farnham: Ashgate

Whitesell, Lloyd (2008) The Music of Joni Mitchell. Oxford and New York: Oxford University Press.

\section{Audio Visual References}

Joni Mitchell, “All I Want”, Blue, 1971, Reprise Records, MS2038, US. 